Kömüves Zsolt, ${ }^{1}$ Szabó Szilvia ${ }^{2}$

\title{
A koronavírus probléma vs. lehetőség? Az országos KoronaHR kutatás részeredményei
}

\author{
DOI 10.17047/Hadtud.2021.31.E.173
}

\begin{abstract}
A koronavírus olyan szakmai és emberi kihívás elé állított minden szervezetet, mellyel korábban nem találkozhatott. Az ehhez hasonló soktényezős, globális válság úgy igényli a legmagasabb fokú figyelmet, hogy közben a kezeléséhez szükséges minimális tapasztalatunk sincs meg, ám ha véletlen adottak is az eszközök, a tudásunk akkor is tesztelésre vár. A kutatási eredmények felhívják a figyelmet arra, hogy a válság egyben pozitív hozadékkal is bírhat a szervezetek életére nézve, de kiemel olyan fejlesztendő területeket is, amely a krízis helyzet eredményeképpen a figyelem középpontjába került.
\end{abstract}

KULCSSZAVAK: Covid-19, HRM, munkaerő-megtartás, motiváció, digitalizáció

\section{The COVID-19: problem vs. opportunity?}

COVID-19 posed a professional and human challenge to every organisation it had never encountered before. A multifactorial global crisis such as this requires the highest level of attention while we do not have the minimum experience to handle. Perchance the tools are given, our knowledge still has to be tested. The research results point out that the crisis can also positively affect the lives of organisations and highlight areas for improvement that have come to the forefront of attention because of the crisis.

KEYWORDS: COVID-19, HRM, labour-retention, motivation, digitization

\section{Bevezetés}

A koronavírus-válság földrajzi kiterjedtsége miatt az első olyan globális kihívásnak tekinthető, amely kivétel nélkül minden országot érint. Ilyen erősségü kölcsönös függőség és összekapcsoltság még nem hozta egymáshoz közel az emberiséget ${ }^{3}$. A járvány alapjaiban változtatta meg az emberek mindennapjait, és súlyos társadalmi és gazdasági következményeket okozott. Hatásos vakcina hiányában az érintett országok speciális intézkedéseket vezettek be, amelyek a mindennapos magatartási szabályok ajánlásától a legszigorúbb korlátozásokig terjedtek. Az esetek többségében szükségessé vált a haderő bevonása is a válság kezelésébe. ${ }^{4}$ A haderő alkalmazása szigorú szabályok és pontosan kidolgozott tervek szerint történik. Feladatuk az egészségügyi válsághelyzetekben a polgári, katasztrófavédelmi feladatok keretében végrehajtott lakosságvédelmi intézkedésekre

\footnotetext{
${ }^{1}$ Egyetemi docens, PhD; Magyar Agrár- és Élettudományi Egyetem - Hungarian University of Agriculture and Life Sciences; komuves.zsolt.sandor@uni-mate.hu

2 Egyetemi docens, $\mathrm{PhD}$; Budapesti Metropolitan Egyetem - Budapest Metropolitan University; szszabo@metropolitan.hu

${ }^{3}$ Matus 2020,46.

${ }^{4}$ Kádár 2021, 3.
} 
korlátozódik. ${ }^{5}$ Hangsúlyozandó azonban, hogy katonai erő bevonására általában csak azon esetekben kerül sor, amennyiben a védekezésre kijelölt szervek munkája nem elégséges a veszélyek, károk elhárítására vagy kezelésére. ${ }^{6}$ Fontosnak tartjuk hangsúlyozni, hogy a járvány sikeres kezelése érdekében a társadalom valamennyi rétege drasztikus változtatásokra kényszerült az egészség és a biztonság megóvása érdekében. A változtatás igénye a vállalatokat sem kerülte el, hiszen súlyos döntéseket kellett hozni a munkaerő megtartása érdekében. Különösen nagy kihívást jelentett annak megoldása, hogy hogyan segítsék a munkatársaikat alkalmazkodni és megbirkózni a munka és a társadalmi életben bekövetkező változásokkal. Például hogyan valósítható meg a home office anélkül, hogy akár a munkáltató vagy a munkavállaló érdeke ne sérüljön? Hogyan biztosítható a munka és a magánszféra közötti szegmentálódás ${ }^{7}$ ?

E kutatásban azokkal a kérdésekkel foglalkozunk, hogy a pandémia megjelenésével és az általa okozott változásokkal szemben a szervezetek milyen válaszokat, megoldási utakat és gyakorlatokat alkalmaztak. Jellemzően problémaként vagy kihívásként, esetleg lehetőségként élik/élték-e meg a mostani válságot?

\section{Covid-19 által okozott gazdasági hatások}

2020 eleje óta a COVID-19 súlyosan befolyásolja az emberek mindennapjait világszerte. ${ }^{8} \mathrm{Az}$ országok különböző stratégiák megvalósításával igyekeznek megfékezni a különböző szektorokra eltérő mértékben ható koronavírus terjedését. Felmerül a kérdés, hogy ezeknek a stratégiáknak milyen a gazdaságra gyakorolt hatása, ${ }^{9}$ adott vállalkozás mennyire veszi figyelembe a humanitárius megoldásokat. ${ }^{10} \mathrm{Az}$ ÁSZ elemzése ${ }^{11}$ szerint a COVID-19 járvány következtében kialakult gazdasági válság hatására a világ GDP-je 3-10\%-al csökkent. A KSH tanulmánya ${ }^{12}$ arra mutat rá, hogy az EU GDP-je a 2020 első és harmadik negyedévben 7\%-al maradt el a 2019-es év azonos időszakához képest. Magyarország esetében a GDP 5,5\%-al csökkent a 2020. év első kilenc hónapjában. Az Európai Bizottság ${ }^{13}$ prognózisa azt jelzi elöre, hogy a magyar GDP 2020-ban 6,4\%-al csökken, miközben a GDP arányos költségvetési hiánya 8,4\%-ra nő. Idén várhatóan a GDP arányos államadóság 78\%-ra nő. Ez a súlyos visszaesés a magyar gazdaság valamennyi szektorát érinti, de különböző mértékben. Poór et $\mathrm{al}^{14}$ kutatócsapata azt vizsgálta, hogy a világjárvány hatására hazánkban hogyan változnak meg a munkaerőpiaci trendek. A kutatók szerint a koronavírus közép-európai megjelenése elött a szervezetek döntő többsége munkaerőhiánnyal küszködött, illetve folyamatosan emelkedtek a bérek. A válság hatására azonban újra megnőtt a munkanélküliségi ráta,

\footnotetext{
${ }^{5}$ Hornyacsek 2018, 73.

${ }^{6}$ Farkas 2017, 44.

${ }^{7}$ Chawla 2020, 19.; Joel B 2020, 183.

${ }^{8}$ Opatha 2020, 37.

${ }^{9}$ Karnon 2020, 335.

${ }^{10}$ Jenei 2020, 53

11. https://www.asz.hu/storage/files/files/elemzesek/2020/covid_20200629.pdf?download=true

12 http://www.ksh.hu/docs/hun/xftp/idoszaki/mone/20203/magyarorszag_2020_iii_negyedev.pdf

${ }^{13} \mathrm{https} / / /$ ec.europa.eu/info/sites/default/files/2021-hungary-convergence-programme_hu.pdf

14 Poór 2020, 66.
} 
csökkentek a bérek. Fontos hangsúlyoznunk, hogy a jó alkalmazottak elvesztése a tudás elvesztését is jelenti, ${ }^{15}$ míg megtartása segíthet a szervezeteknek megőrizni a tudást és a tapasztalatot. ${ }^{16}$ A vállalkozások valamennyi munkatársért felelősséggel tartoznak. ${ }^{17}$

\section{A Covid és a HR kapcsolata}

A munkáltató és a munkavállaló közös érdeke, hogy a pandémia ideje alatt az üzletmenet zavartalanul müködjön, a munkáltató továbbra is foglalkoztassa a munkavállalót, aki ezért megkapja a munkabérét, így elkerülhetőek a tömeges leépítések és elbocsátások. ${ }^{18}$ Hangsúlyoznunk kell azonban, hogy a pandémia következményeként végrehajtott korlátozási intézkedések és a mobilitási korlátozások jelentősen átalakították a munkaerő-piacon általánossá vált $\mathrm{Hr}$ gyakorlatokat. A szervezetek többsége válaszként az alábbi fontos intézkedéseket hozta meg: leállította az üzleti utakat, céges rendezvényeket továbbá az otthoni munkát engedélyezte, illetve elrendelte. A döntések meghozatala során a vezetésnek két fontos kérdést kellett mérlegelni: mely dolgok a legfontosabbak a munkavállalók számára, és ezzel együtt mi a HR számára? A járvány alatt az alkalmazottak számára a legnagyobb kihívást a munka és a magánélet egyensúlyának megteremtése jelentette. ${ }^{19} \mathrm{~A}$ válság következményeként olyan jelenségeknek lehettünk tanúi, mint a társadalmi elszigeteltség, szegregáció, bizonytalanság és a félelemérzet kialakulása. Ebben a helyzetben a szervezeteknek rugalmasabbaknak és innovatívabbaknak kell lenniük a munkavállalóikat érintő váratlan emberi erőforrásokkal kapcsolatos kérdésekben. ${ }^{20}$ Azt is látnunk kell, hogy a munkavállalót inkább az anyagi biztonság, a személyes és a családi egészség foglalkoztatja, mint a munkáltatója anyagi helyzete, instabillá válása, ezért a HR stratégiának figyelembe kell venni a munkavállalók aggodalmait. ${ }^{21}$ A szervezetek számára a legnagyobb megmérettetést a hatékony belső kommunikáció, tájékoztatás és a kapcsolattartás jelenti. Ezt követi a munkaerő megtartásának nehézsége, a home office, távmunka bevezetése/müködtetése, illetve az egészségvédelem és a higiéniai elöírások betartása. ${ }^{22}$ Kritikus pontként említésre került a motiváltság fenntartása, a bérgazdálkodás, a pánik kezelése és a digitális folyamatok kialakítása. A jövőben olyan stratégiák kialakítására kell törekedni, melyek gyakorlati alkalmazása hozzájárul a munkaerő és a megváltozott munkaerő-piaci körülmények közötti kapcsolat egyensúlyának megteremtéséhez, valamint szorgalmazni szükséges a hatékony tanulási formák kialakítását a digitális transzformáció adta lehetőségek maximális kiaknázásával. Fontos azt is hangsúlyoznunk, hogy a szervezeti fejlődés és a HR

\footnotetext{
15 Ramlall 2004, 53.

16 Al-Dalahmeh et al. 2020.

${ }^{17}$ David 2019, 14.; Hegedüs 2018, 185.

18 https://www.pwc.com/hu/hu/kiadvanyok/assets/pdf/Kenyszerpiheno_helyett_tulorak_avagy_kik_a_COVID-

19_nyertesei.pdf Letöltés ideje: 2021.04. 26

${ }^{19}$ Pirohov 2020, 404.

${ }^{20}$ Gelencsér 2020, 68.

${ }^{21} \mathrm{https}$ ///europepmc.org/article/ppr/ppr245459

22 Poór 2020, 32.
} 
mozgatórugója a kreativitás és az innováció, ${ }^{23}$ amelyet az emberi erőforrás birtokol humán tőkeként, így a közeljövőben ennek a szerepe hatványozottan fel fog erősödni.

\section{Anyag és módszer}

A COVID-19 okozta első európai megbetegedések után néhány hónappal, 2020 májusának elején a Humán Szakemberek Országos Szövetsége (HSZOSZ), az Országos Humánmenedzsment Egyesület (OHE) és a Magyar Hadtudományi Társaság (MHTT) kezdeményezésére és támogatásával tizenhárom magyarországi és egy határon túli egyetem kutatóinak összefogásával Magyarországon létrejött a KoronaHR kutatócsoport, melynek fő céljai az alábbiakban foglalhatók össze. ${ }^{24}$

1. Kövessük nyomon, hogy milyen változásokkal reagál a hazai vállalati/intézményi szféra emberi erőforrás menedzselési gyakorlata a koronavírus okozta válság kihívásaira a pandémia első és második fázisában!

2. Segítsük az elmélet és a gyakorlat közötti kapcsolat fejlesztését!

3. Egyetemi együttmüködések keretében alapozzuk meg a válsághoz és kilábaláshoz kapcsolódó HR ismeretkörök továbbfejlesztését, tananyagba illesztését!

4. Együttmüködésünkkel támogassuk a koronavírus elleni országos erőfeszítések minél jobb megalapozását, úgy is, hogy lehetővé tesszük, hogy a résztvevők az eredmények disszeminációját minél magasabb szintű publikációk révén tegyék elérhetővé!

A cikk szerzői a KoronaHR kutatócsoport tagjai, tanulmányukat és az eredményeik bemutatását a kutatás adatbázisa alapján készítették el. Az online kutatás első hulláma 2020. június 12. és július 31. között valósult meg. A vizsgálat második fázisának adatfelvétele amely alapján a dolgozat készült - 2020. augusztus 1. és november 15. közötti időintervallumban valósult meg. Az első időszakban 508 értékelhető kérdőív érkezett vissza, a második fázisra 1010 szervezet adott választ a feltett kérdéseinkre (1. táblázat).

\section{1. táblázat}

A válaszadó szervezetek méret szerinti megoszlása a második hullám adatfelvétele során

(Forrás: KoronaHR kutatás 2020 adatai alapján saját számítás)

\begin{tabular}{|c|c|}
\hline Méret & $\begin{array}{c}\text { Válaszadó szervezetek } \\
\text { száma }\end{array}$ \\
\hline $1-9$ fö & 177 \\
\hline $10-49$ fö & 217 \\
\hline $50-250$ fö & 218 \\
\hline $251-500$ fö & 89 \\
\hline $5001-2000$ fö & 141 \\
\hline 2000 fö felett & 137 \\
\hline szervezet senkit sem foglalkoztat & 31 \\
\hline Összes válaszadó & $\mathbf{1 0 1 0}$ \\
\hline
\end{tabular}

\footnotetext{
${ }^{23}$ Hegedüs 2017, 95.

${ }^{24}$ Poór 2020, 9.
} 
A vizsgálatba résztvevő szervezetek bruttó árbevétel szerinti felosztását a 2. táblázatban tüntettük fel.

2. táblázat

A válaszadó szervezetek bruttó árbevétel szerinti megoszlása a második hullám adatfelvétele során (Forrás: KoronaHR kutatás 2020 adatai alapján saját számítás)

\begin{tabular}{|c|c|}
\hline Méret & $\begin{array}{c}\text { Válaszadó szervezetek } \\
\text { száma }\end{array}$ \\
\hline 50 millió Ft alatt & 217 \\
\hline $51-100$ millió $\mathrm{Ft}$ & 102 \\
\hline $101-500$ millió $\mathrm{Ft}$ & 164 \\
\hline $501-2,5$ milliárd $\mathrm{Ft}$ & 175 \\
\hline $2,51-25$ milliárd $\mathrm{Ft}$ & 149 \\
\hline $25,1-120$ milliárd $\mathrm{Ft}$ & 77 \\
\hline 120 milliárd Ft felett & 99 \\
\hline Összes válaszadó & $\mathbf{9 8 3}$ \\
\hline
\end{tabular}

Empirikus vizsgálatunk ex-post jellegü volt, azaz a megfigyelési időszakkal kapcsolatos véleményekre és tényadatokra támaszkodva vizsgáltuk a COVID-19 koronavírus okozta válság hazai vállalati/intézményi szféra emberi erőforrás menedzselési gyakorlatára kifejtett hatását. Az általunk használt kérdőívben zárt és nyílt végű kérdések egyaránt szerepeltek. A zárt végü kérdések esetében a válaszadóktól a vizsgálat témaköreit nagymértékben lefedő, előre megfogalmazott válaszok közül a legjellemzőbbek megjelölését kértük egyválaszadós (one-respondent) módon. A válaszokat SPSS 26.0 program segítségével elemeztük. Kutatási modellünk az 1. ábrán látható.

\begin{tabular}{|c|c|c|c|c|c|}
\hline \multicolumn{2}{|c|}{ Átalakítás } & \multicolumn{2}{|c|}{ Reakciók/lehetôségek } & \multicolumn{2}{|c|}{ Átalakítás } \\
\hline \multicolumn{2}{|c|}{ Szervezet } & Általános & $\mathrm{HR}$ & \multicolumn{2}{|c|}{$H R$} \\
\hline \multicolumn{2}{|c|}{ Koronavírus } & \multicolumn{2}{|c|}{$\begin{array}{c}\text { A vizs gált szervezetek } \\
\text { jellemzối }\end{array}$} & \multicolumn{2}{|c|}{ Koronavírus } \\
\hline Hatások & $\begin{array}{l}\text { Teremtette } \\
\text { lehetôségek }\end{array}$ & Általános & HR & Hatások & $\begin{array}{l}\text { Teremtette } \\
\text { lehetôségek }\end{array}$ \\
\hline \multicolumn{2}{|c|}{ Munkakörök } & \multicolumn{2}{|c|}{ Reakciók/lehetôségek } & \multicolumn{2}{|c|}{ Kompetenciák } \\
\hline Pozitiv/új & $\begin{array}{l}\text { Negativ/ } \\
\text { megszûnỗ }\end{array}$ & Általános & $\mathrm{HR}$ & Pozitiv/új & $\begin{array}{l}\text { Negativ/ } \\
\text { megszûn nỗ }\end{array}$ \\
\hline
\end{tabular}

1. ábra

A KoronaHR kutatási keretmodell

(Forrás: Poór et al. 2020) 
A felmérés során alkalmazott kérdőívünk a következő nagyobb kérdéscsoportokkal foglalkozik:

1. a koronavírus okozta válság jelenlegi és várható hatásai a magyar gazdaságra és a vizsgált szervezetre,

2. a vizsgált szervezetre leginkább jellemző általános és HR válságkezelö intézkedések,

3. a vizsgált szervezeteknél a válság hatására a HR-területen kezdeményezett (megvalósul vagy tervezett) változások/változtatások,

4. a koronavírus válság által teremtett fejlesztési, fejlődési lehetőségek a vizsgált szervezetnél és annak HR szervezetében,

5. a válság hatásai által pozitívan és/vagy negatívan érintett munkakörök és kompetenciák,

6. a vizsgált szervezet, a válaszadó HR-terület és a válaszadó személy jellemzői.

Jelen elemzés - a második hullámban felvett adatokra támaszkodva - a negyedik pont eredményeinek részletes kifejtésével foglalkozik.

\section{Eredmények}

Elemzésünket egy sor megválaszolandó kérdéssel indítjuk, amelyek fontos szerepet játszanak az eredmények értékelésénél/bemutatásánál. Kutatási kérdéseink tehát az alábbiak:

Mely vállalat gondolta volna az éves pénzügyi tervezésnél, hogy veszélybe kerülhet a müködése, alkalmazottai nem tudnak majd bemenni dolgozni vagy, hogy a külföldről beszerzett alapanyagok nem fognak időben megérkezni? Legalább ennyire fontos kérdés az is, hogy a szervezetek egy válság vagy bármilyen vis major helyzetre fel vannak-e készülve? Rendelkeznek-e válság-forgatókönyvvel, amely tételesen rögzíti a legfontosabb teendőket? Ennek megfelelően kutatásunkban rákérdeztünk arra, hogy az általunk vizsgált vállalkozásoknak van-e intézkedési terve, mely részletesen tartalmazza a rendkívüli helyzetekben alkalmazandó protokollt (kommunikáció, munkaszervezés, védekezés) (3. táblázat)?

\section{3. táblázat}

A szervezeti méret és az intézkedési terv kapcsolata

(Forrás: KoronaHR kutatás 2020 adatai alapján saját számítás)

\begin{tabular}{|l|c|c|c|c|c|}
\hline & $\begin{array}{c}\text { A vírushelyzetet } \\
\text { megelözöen volt } \\
\text { már(\%) }\end{array}$ & $\begin{array}{c}\text { A vírushelyzetet } \\
\text { megelözöen volt, } \\
\text { de azt } \\
\text { módositottuk (\%) }\end{array}$ & $\begin{array}{c}\text { Nem volt, de a } \\
\text { vírus helyzet } \\
\text { miatt } \\
\text { kidolgoztunk (\%) }\end{array}$ & $\begin{array}{c}\text { Nincs, de } \\
\text { tervezzük(\%) }\end{array}$ & $\begin{array}{c}\text { Nem látjuk } \\
\text { értelmét (\%) }\end{array}$ \\
\hline 1-9 fö & 7,90 & 5,64 & 47,45 & 17,51 & 21,46 \\
\hline $10-49$ fö & 10,18 & 7,40 & 59,25 & 10,64 & 12,50 \\
\hline 50-250 fó & 8,71 & 15,59 & 66,97 & 5,04 & 4,12 \\
\hline 251-500 fö & 14,60 & 22,47 & 57,30 & 4,49 & 1,12 \\
\hline 501-2000 fö & 10,63 & 23,40 & 63,82 & 2,12 & 0 \\
\hline 2000 fö felett & 14,70 & 40,44 & 41,91 & 0,73 & 2,20 \\
\hline $\begin{array}{l}\text { szervezet senkit } \\
\text { sem foglalkoztat }\end{array}$ & 12,90 & 0 & 19,35 & 19,35 & 15 \\
\hline
\end{tabular}


Az eredmények alapján azt mondhatjuk, hogy a vizsgált szervezetek 11,37\%-nak volt válsághelyzetre kidolgozott stratégiája. 16,42\% rendelkezett valamilyen intézkedési tervvel, de azt módosítani kellett, annak érdekében, hogy az adaptálható legyen a koronavírus járvány hatásainak kezelésére. A válaszadó szervezetek 8,05\%-a azonban feleslegesnek tartja ilyen dokumentum elkészítését. Fontos azt is kiemelni, hogy minél magasabb volt a vizsgált szervezet foglalkoztatotti létszáma, annál nagyobb volt a valószínüsége annak, hogy rendelkezett- valamilyen cselekvési tervvel, vagy éppen a meglévő egyéb válsághelyzetre kidolgozott intézkedéscsomagot a járvány alakulásának megfelelően átdolgozták. A kérdésre adott válaszok alapján a szervezet mérete és a cselekvési terv megléte között szignifikáns kapcsolatot találtunk, ahol $\mathrm{c}=0,260$ és a $\mathrm{p}=0,000$. Hasonló kapcsolat mutatható ki az intézkedési terv megléte és a szervezet éves bruttó árbevétele között is, ahol c=0,186 és a $\mathrm{p}=0,000$. A COVID-19 által előidézett kihívások között az egyik legjelentősebb probléma talán a bizonytalanság növekedése a legtöbb szervezet életében, különös tekintettel az emberi munkaerő-megtartására vonatkozólag. A SARS-CoV-2 globális járványként való megjelenése óta sok szervezet elbocsátotta munkavállalóit, elvesztette ügyfeleit, és ez nagyban befolyásolta a szervezetek jövedelmezőségi szintjét, föleg az emberi erőforrások hatékonyságának és termelékenységének romlása miatt. A vállalkozások jelentős hányada felkészületlenül sodródott a kialakult helyzettel. A gazdasági hatások iparáganként és szervezetenként változóak voltak, attól függően, hogy az érintett szervezetek hogyan tudtak alkalmazkodni a megváltozott helyzethez. A válaszlépések kialakítása során fontos kérdés, hogy a vizsgált szervezetek miként tekintettek a kialakult válságra, láttak-e lehetőségeket, fel tudtak-e vázolni megoldási alternatívákat? A 4. táblázat e kérdéseket igyekszik megválaszolni. A válaszadó szervezeteknek 1-7 terjedő skálán kellett értékelni azt, hogy vajon a koronavírus jelent-e számukra bármilyen fajta lehetőséget, megteremtett-e olyan cselekvési tervet, esetleg motivációt olyan feladatok elvégzésére, amelyre a kialakult válság hívta fel a figyelmet/vagy adott lehetőséget.

\section{4. táblázat}

A koronavírus járvány jelent-e bármilyen fajta lehetőséget szervezete számára

(Forrás: KoronaHR kutatás 2020 adatai alapján saját számítás)

\begin{tabular}{|c|c|}
\hline Szempontok & Értékek \\
\hline Átlag & 4,22 \\
\hline Medián & 4 \\
\hline Módusz & 4 \\
\hline Összes válaszadó & $\mathbf{9 8 2}$ \\
\hline
\end{tabular}

Az eredmények azt mutatják, hogy a válság számos negatív hatásán túl a válaszadó szervezetek számára pozitív hozadékkal is bírt. Kérdésként merül fel, hogy vajon van-e kapcsolat a szervezet mérete és a pandémiás válság lehetőségként kezelése között (5. táblázat)? 
5. táblázat

A szervezet mérete és a koronavírus járvány lehetőségként történö kezelése közötti kapcsolat

(Forrás: KoronaHR kutatás 2020 adatai alapján saját számítás)

\begin{tabular}{|l|c|c|c|}
\hline & Egyetért (6) & Teljesen egyetért (7) & $\begin{array}{l}\text { Együtt a teljes } \\
\text { mintán belül (\%) }\end{array}$ \\
\hline $1-9$ fö & 11 & 19 & 17,04 \\
\hline $10-49$ fö & 21 & 34 & 26,82 \\
\hline $50-250$ fö & 25 & 35 & 214 \\
\hline $251-500$ fö & 9 & 11 & 28,37 \\
\hline $501-2000$ fö & 13 & 26 & 28,88 \\
\hline 2000 fö felett & 18 & 31 & 36,56 \\
\hline
\end{tabular}

A táblázat eredményei alapján megállapíthatjuk, hogy minél nagyobb a szervezet, annál nyitottabb a koronavírus járványból fakadó lehetöségek megragadására. A kereszttáblás vizsgálatok eredményei alapján szignifikáns kapcsolat mutatható ki a szervezet foglalkoztatotti létszáma és a járvány pozitív hozadékként való megítélése között, ennek értékei: $\mathrm{c}=0,101$ és $\mathrm{p}=0,008$. Az ANOVA program segítségével megnéztük, hogy a válaszadó szervezetek, a válság következtében, miként vélekednek a potenciálisan fejlődö, HR területekröl (6. táblázat).

6. táblázat

A válság következtében potenciálisan fejlödö, erösödö HR területek

(Forrás: KoronaHR kutatás 2020 adatai alapján saját számítás)

\begin{tabular}{|l|c|}
\hline \multicolumn{1}{|c|}{ A válság potenciális fejlödési lehetőséget jelent az Ön cége számára } & $\begin{array}{c}\text { Szignifikancia } \\
(p) \text { értéke }\end{array}$ \\
\hline Létszámtervezés/veszteségidő csökkentés & 0,000 \\
\hline Toborzási, kiválasztási rendszerek fejlesztése & 0,000 \\
\hline Home office/adminisztrációs költségek csökkentése & 0,000 \\
\hline Ösztönzés és javadalmazás menedzsment & 0,012 \\
\hline Szociális, mentális támogatás & 0,005 \\
\hline Munkavédelem & 0,003 \\
\hline Belső kommunikáció/digitalizáció fejődése & 0,000 \\
\hline
\end{tabular}

Az egyik ilyen kedvező hatás, az adminisztrációs költségek megtakarítása azáltal, hogy a személyzet home office-ban dolgozik. További előnyök a veszteségidő csökkenése azáltal például, hogy kiesik az alkalmazottak napi ingázásának ideje a munkahely és az otthon között, az ebédre és a kávé szünetekre fordított időtartam. Költségmegtakarítást eredményezhet, hogy a vállalkozásoknak nem kell nagy készleteket fenntartani, irodát bérelni és ösztönözni a személyzetet otthoni munkavégzésre. Fejlödés mutatkozott a belső kommunikáció terén is. A kommunikáció normál müködés mellett is fontos, ${ }^{25}$ de az otthoni munkavégzés során ez fokozottan igaz. Az új technológiák széles skálájának megjelenése azt eredményezi, hogy az

${ }^{25}$ Dajnoki 2010, 65. 
iparágak és a foglalkozások radikálisan átalakulnak. A „digitális forradalom” által megtapasztalt előnyöket nagy valószínüséggel a válságot követően is hasznosítani fogják a szervezetek. ${ }^{26}$ A technika és a digitalizáció révén lehetővé vált, hogy a korábban megszokott gazdasági, társadalmi tevékenységek egy része helyváltoztatás és személyes találkozások nélkül is megvalósítható legyen a digitális világban, az információs társadalomban. ${ }^{27} \mathrm{~A}$ pandémiás válság lehetőséget teremtett a toborzási, kiválasztási stratégiák újragondolására is. A vírus ideje alatt a személyes interjúk lefolytatására nem volt lehetőség, így a meglévő technikákat kellett hatékonyabbá, korszerübbé tenni. Az online meghallgatások számos előnyt kovácsolnak a munkaadók számára, például egyszerübben tervezhetők, kevésbé stresszes, oldottabb, nem igényel fizikai jelenlétet. A COVID-19 idején hangsúlyos szerep jutott a munkáltatóknak a dolgozók mentális és szociális támogatásában is, hiszen a karantén, a home office számos negatív hatást gyakorolt a dolgozókra, így pl. a rossz hangulat, stressz, alvászavar, ingerlékenység, depresszió, kiégés. A fejlődő területek elemzésekor feltétlenül szólnunk kell a munkavédelem erősödő szerepéről is. A kormányzati szándék az volt, hogy korlátozások helyett az ország müködőképességét kell biztosítani a vírus elleni védekezésben. Így valamennyi vállalkozás fókuszába a munkavédelem és az egészségmegőrzés került (maszkviselés, társadalmi távolságtartás). Nyilvánvalóvá vált, hogy minden szervezetnek szüksége van egy egyértelműen meghatározott stratégiára, amely rámutat a szervezet jövőképének és küldetésének irányára. ${ }^{28} \mathrm{~A}$ stratégiai tervezés ugyanis javítja a szervezeti teljesítményt, ami hosszú távon hatással van mind a jövedelmezőségre mind a humán erőforrás megtartására és müködtetésére. ${ }^{29}$ Fontos hangsúlyoznunk, hogy a krízismenedzsment még soha nem volt ennyire fókuszban, mint a COVID-19 kapcsán, hisz jelen helyzet megmutatta a világ sebezhetőségét, miután a járvány tönkretette a globális gazdaságot. ${ }^{30}$ Ezért nagy szükség van a vállalatoknál a krízismenedzserek és stratégiai tervezők közös együttmüködésére a legjobb megoldás létrehozására. A megfelelő stratégiai tervezéssel, a vállalatok képesek lesznek a különböző krízisek típusának megállapítására, ahhoz kapcsolódó források hozzárendelésére és a legalkalmasabb válságkezelési mód kiválasztására.

\section{7. táblázat}

Fejlesztendö területek megítélése a válaszadó szervezetek véleménye alapján

(Forrás: KoronaHR kutatás 2020 adatai alapján saját számítás)

\begin{tabular}{|l|c|}
\hline \multicolumn{1}{|c|}{ Fejlesztendö területek } & $\begin{array}{c}\text { Szignifikancia } \\
(p) \text { értéke }\end{array}$ \\
\hline Belsö kommunikáció fejlesztése & 0,000 \\
\hline Ösztönzési/bérezési rendszer átalakítása & 0,012 \\
\hline Utánpótlás tervezés & 0,011 \\
\hline
\end{tabular}

\footnotetext{
${ }^{26}$ Strielkowski 2020, 2.

${ }^{27}$ Zádori 2020, 10.

${ }^{28}$ John 2020, 36.

${ }^{29}$ Monye 2018, 31.

${ }^{30}$ Poór 2021, 51.
} 
A leírtaknak megfelelően a HR-nek számos feladatot kell újragondolnia a hatékonyság jegyében (7. táblázat). Ilyen feladatok például az emberek motivációja, képzése és fejlesztése, az adminisztrációs feladatok optimalizálása, valamint az utánpótlás tervezés szükségessége. A belső kommunikáció komoly fejlesztésen ment keresztül a válság által szült kényszerhelyzetben, de a vállalkozások még kiaknázatlan területeket látnak ebben, így ennek a jövőbeni fejlesztése a hatékonyság növelés egyik fontos záloga is egyben. Másik fontos fejlesztendő terület, amellyel a cégvezetőknek és a HR-eseknek meg kell küzdeni, hogy miként lehet motiválni a dolgozót a járvány idején, a négy fal között? Lehet-e, kell- e az otthoni munkavégzés eredményességét, hatékonyságát mérni? Egyáltalán, hogyan lehet valaki jó fönök a válság idején? Vannak stratégiák, amelyeket a vezetés alkalmazhat a munkavállalók ösztönzésére, az elégedettségük, biztonságérzetük növelésére kifejezetten a pandémia idején. ${ }^{31}$ Így például hangsúlyozásra került az információkhoz való hatékony hozzáférés illetve a megfelelő minőségü tájékoztatás szerepe. A gyorsított ütemü átállás és reagálás nagy kihívás elé állította a szervezeteket. Fókuszba került az utánpótlás tervezés szükségessége. Központi kérdés, hogy van-e a szervezetnél olyan tehetséges, ambiciózus munkavállaló, aki rendelkezik azokkal a készségekkel és képességekkel, amely alapján be lehet vonni a szervezet vezetésébe, a folyamatok fenntartásába és fejlesztésébe a közös és kölcsönös haszonmaximalizálás érvényesítésével egy súlyos válság, krízishelyzet idején, ha a vállalkozás vezetője rövidebb vagy hosszabb ideig kiesik a cég irányításából. Ezt a kérdést az ANOVA program segítségével összevetettük a szervezet árbevételével is, amelynek eredményeit a 8. táblázatban láthatjuk.

\section{8. táblázat}

A szervezetek árbevétele és a fejlesztendö HR területek kapcsolata

(Forrás: KoronaHR kutatás 2020 adatai alapján saját számítás)

\begin{tabular}{|l|c|}
\hline \multicolumn{1}{|c|}{ Fejlesztendö területek } & $\begin{array}{c}\text { Szignifikancia } \\
(p) \text { értéke }\end{array}$ \\
\hline Ösztönzési / bérezési rendszer & 0,016 \\
\hline Belső kommunikáció & 0,000 \\
\hline Adminisztráció & 0,043 \\
\hline Utánpótlás tervezés & 0,020 \\
\hline Képzés & 0,000 \\
\hline Jóléti programok & 0,003 \\
\hline
\end{tabular}

Az előzőekben említett szempontokon túl, megjelenik a képzés iránti igény is. A COVID-19 járvány kapcsán elrendelt kormányzati és szervezeti intézkedések révén sokan home office munkavégzésre kényszerültek. Ennek során megoldandó feladatként jelentkezett a munkaadók számára a munkavállalók képzése, amelynek igényét az informatikai ismeretek hiánya és a gyakorlatlanság predesztinált. Ezáltal szükségessé vált egy jó munkaeröbiztosítási terv elkészítése is annak érdekében, hogy a képzésekre azelőtt sor kerülhessen, mielött az adott munkatársak először szembesülnének új feladataikkal. A koronavírus járvány

31 Ashraf 2020, 5059. 
eredményeképpen egyre több munkáltató ismerte fel a wellbeing jelentőségét és szerepét abban, hogy a munkavállalók jóléte és motivációja, illetve teljesítménye szorosan összefügg egymással. Ezért e terület erősítése mindenképpen a jövőben további támogatást igényel.

\section{Következtetések és javaslatok}

A kutatás során az alábbi következtetéseket fogalmazzuk meg:

- a vizsgált szervezetek 11,37\%-nak volt válsághelyzetre kidolgozott stratégiája. 16,42\% rendelkezett valamilyen intézkedési tervvel, de azt módosítani kellett, annak érdekében, hogy adaptálható legyen a koronavírus járvány hatásainak kezelésére. A válaszadó szervezetek 8,05\%-a azonban feleslegesnek tartja az ilyen dokumentumok elkészítését.

- Megállapítást nyert, hogy minél nagyobb a szervezet mérete, annál ellenállóbb a megnövekedett költségek és az alacsonyabb árbevétellel szemben.

- A koronavírus járvány a válaszadó szervezetek számára pozitív hozadékkal is bírt, így potenciálisan fejlődő területekként: a létszámtervezés/veszteségidő csökkentés, toborzási, kiválasztási rendszerek fejlesztése, home office/adminisztrációs költségek csökkentése, ösztönzés és javadalmazás menedzsment, szociális, mentális támogatás, munkavédelem, belsö kommunikáció/digitalizáció fejődése került említésre.

- A járvány az alábbi fejlesztendő területekre hívta fel a figyelmet: belső kommunikáció fejlesztése, ösztönzési/bérezési rendszer átalakítása, utánpótlás tervezés.

Munkánk során az alábbi javaslatokat fogalmazzuk meg:

- Elengedhetetlenül fontos, hogy minden szervezet átfogó pandémiás intézkedési tervet készítsen, melyben világosan rögzíti a járvány terjedésének időszakára vonatkozó átmeneti szabályokat és az alkalmazandó prevenciós rendelkezéseket.

- Fontos szerepet kell szánni a jövőben a munkaerö-biztosítási terv elkészítésére, amely magába foglalja a munkaerö-tervezést, kiválasztást és a képzések megvalósításának részleteit.

- A belső kommunikáció fejlesztése elengedhetetlen minden szervezet életében, mivel ezzel csökkenthetö a bizonytalanság a szervezet jövőjét és a dolgozó szerepét illetően.

\section{FELHASZNÁLT SZAKIRODALOM}

Al-Dalahmeh, Maha Lutfi - Héder-Rima, Mária - Dajnoki, Krisztina 2020. The effect of talent management practices on employee turnover intention in the Information and Communication Technologies (ICTs) sector: case of Jordan. Problems and Perspectives in Management 18:4, 59-71.

Állami Számvevőszék: Járványhelyzet és munkaerőpiac, Letöltés ideje: 2020. október 10. https://www.asz.hu/storage/files/files/elemzesek/2020/covid_20200629.pdf?ctid=1296

Ashraf Saeed Elsafty - Mohammad Ragheb 2020. The Role of Human Resource Management Towards Employees Retention During Covid-19 Pandemic in Medical Supplies Sector Egypt, Business and Management Studies 6 (2): 5059 ISSN: 2374-5916 E-ISSN: 23745924 Published by Redfame Publishing, 
Chawla Nitya - Rebecca L MacGowan - Gabriel Allison - Nathan Podsakoff 2020. Unplugging orstaying connected? Examining the nature, antecedents, and consequences of profilesof daily recovery experiences. Journal of Applied Psychology 105 (1): 19.

Dajnoki Krisztina 2010. Kommunikáció az esélyegyenlőségi emberi erőforrás menedzsmentben. Jelenkori társadalom és gazdasági folyamatok 5 (1): 65-70.

David Forest Redwan 2019. Analyzing croatian and hungarian vision and mission statements in the agribusiness sector. In Gordan, Družić; Tomislav, Gelo (szerk.): Conference Proceedings of the International Conference on the Economics of Decoupling (ICED) $=$ Zbornik radova međunarodne znanstvene konferencije Ekonomija Razdvajanja održane 02.-03. prosinca 2019. u Zagrebu Zagreb, Horvátország: Faculty of Economics \& Business, University of Zagreb, 14.

Farkas Ádám 2017. Adalékok az állam fegyveres védelmének rendszertani megközelítéséhez. Honvédségi Szemle 1 (2): 44-58.

Gelencsér Martin - Szigeti Orsolya - Szabó-Szentgróti Gábor 2020. A feldolgozóipari munkavállalók munkaerő-megtartása, Vezetéstudomány 51 (9): 67-79.

Hegedűs Henrik 2017. A tudás, mint versenyelőny a köz- és a versenyszférában (tudás kompetencia - teljesítmény - siker). Hadtudomány 27 (E-szám): 94-102.

Hegedűs Henrik 2018. Recenzió „A munka világa a 21. század elején. Foglalkoztatáspolitikai és munkaerö-piaci kézikönyv" címü kiadványról. Hadtudomány 28 (E-szám): 185-187.

Hornyacsek Júlia - Nyitrai Mihály 2018. Területi járványügyi veszélyhelyzet egészségügyi és logisztikai támogatása, Hadmérnök 131 (március): 73-96.

Jenei Szonja - Módosné, Szalai Szilvia 2020. A koronavírus járvány hatásai a humánerőforrás-menedzsment különböző területeire 2020-ban. Új Munkaügyi Szemle 2 (2): 53-64.

John-Eke - Ebere Chika 2020. Strategic planning and crisis management styles in organizations, Journal of Strategic Management 5.(1): 36-46. ISSN 2520-0461 (Online)

Joel Carnevale - Isabella Hatak 2020. Employee adjustment and well-being in the era of COVID-19: Implicationsfor human resource management. Journal of Business Research 116 (August): 183-187.

https//doi.org/10.1016/j.jbusres.2020.05.037

Karnon Jonathan 2020. The Case for Temporary COVID-19 Income Tax Levy Now, During the Crisis. Applied Health Economics and Health Policy 18 (3): 335-337.

https://doi.org/10.1007/s40258-020-00585-6

Kádár Pál 2021. A pandémia kezelése mint a nemzeti ellenálló képesség „tesztje”. Honvédségi Szemle 14, (2): 3-13.

https://doi.org/10.35926/HSZ.2021.2.1

Központi Statisztikai Hivatal: Magyarország, 2020. I-III. negyedév. Letöltés ideje: 2021. 05. 04.

http://www.ksh.hu/docs/hun/xftp/idoszaki/mone/20203/magyarorszag_2020_iii_negyedev.pdf 
Magyarország Kormánya: Konvergencia Programja. Letöltés ideje: 2021. 04. 25. https://ec.europa.eu/info/sites/default/files/2021-hungary-convergenceprogramme_hu.pdf

Mala W 2021. How COVID-19 Changes the HRM Practices (Adapting One HR Strategy May Not Fit to All). Letöltés ideje: 2021.04.25. https://europepmc.org/article/ppr/ppr245459 http://dx.doi.org/10.2139/ssrn.3736719

Matus János 2020. Pandémia. Egészségbiztonság és az új világrend. Hadtudomány 30 (2): $39-55$.

Monye, M .C., - Ibegbulem, A. B 2018. Effect of strategic planning on organizational performance and profitability. International Journal of Business \& Law Research 6.(2): $31-40$.

Opatha Henarath 2020. The Coronavirus and The Employees: A Study from the Point of Human Resource Management. Sri Lankan Journal of Human Resource Management 10 (1): 37-49.

Pirohov -Tóth Barbara - Kiss Zsuzsanna 2020. A munkaerő-piaci szereplők által tapasztalt foglalkoztatási kihívások a koronavírus-járvány idején. letöltés ideje: 2021. 04. 28 Opus et Educatio 7

402-409.

http://opuseteducatio.hu/index.php/opusHU/article/view/408/712,

Poór József - Balogh Gábor - Dajnoki Krisztina - Karoliny Mártonné - Kun András István Szabó Szilvia 2020. Koronavirus-válság kihívások és HR válaszok - A kutatás első fázisának kiértékelése. Gödöllő: Szent István Egyetem Gazdaság- és Társadalomtudományi Kar Menedzsment és HR Kutató Központ.

Poór József - Dajnoki Krisztina - Pató Gáborné Szücs Beáta - Szabó Szilvia 2021. Koronavirus-válság kihívások és HR válaszok- Elsö és második fázis összehasonlítása. Gödöllő: Magyar Agrár- és Élettudományi Egyetem.

Pwc kutatás: Kényszer pihenő helyett túlórák, avagy kik a Covid 19 nyertesei. Letöltés ideje: 2021. 04. 26.

https://www.pwc.com/hu/hu/kiadvanyok/assets/pdf/Kenyszerpiheno_helyett_tulorak_avagy_k ik_a_COVID-19_nyertesei.pdf

Ramlall Sunil 2004. "A Review of Employee Motivation Theories and Their Implications for Employee Retention within Organizations." Journal of American Academy of Business 5 (1/2): 52-63.

Strielkowski Wadim: COVID-19 pandemic and the digital revolution in academia and higher education. Letöltés ideje: 2021. $04 . \quad 23 . \quad$ Preprints, https://www.preprints.org/manuscript/202004.0290/v1

Zádori Iván - Nemeskéri Zsolt - Szabó Szilvia 2020. Deglobalizáció vagy reglobalizáció? Munkaerőpiac a vírus előtt, alatt és után. Vitaindító tanulmány. Új Munkaügyi Szemle 1 (3): $2-13$. 